Јелена М. Тодоровић Васић Универзитет у Крагујевцу Филолошко-уметнички факултет Катедра за српску књижевност
УДК 821.163.41-21.09 Лукић В. $821.14^{\prime} 02-21.09$

https://doi.org/10.18485/uzdanica.2020.17.1.3

Оригинални научни рад

Примљен: 28. фебруар 2020.

Прихваћен: 1. јун 2020.

\title{
РЕМИТОЛОГИЗАЦИЈА ЕУРИПИДОВОГ МИТСКОГ ОБРАСЦА У МЕДЕЈИ ВЕЛИМИРА ЛУКИЋА
}

$A \bar{u} c \bar{u} р а к \bar{u}: \mathrm{У}$ раду се бавимо анализом трагедија Велимира Лукића и Еурипида са посебним освртом на трансформисане елементе у трагедијама оба аутора у поређењу са примарним митом о Медеји. Константним освртом на мит и компаративном анализом дискурса трагедија настојаћемо представити сегменте који су сродни и оне који се значајно разликују у наведеним трагедијама. Мит је ритуалног карактера, што доказује и реинтерпретација одређених архетипских, митских прича и личности. Посебно ћемо истаћи сегменте дискурса којима се доказује различит драмски поступак, конкретно различит одабир дела или чак верзије мита који је у спрези са формирањем структуре карактера. Циљ рада је истицање путање трансформације мита преко Еурипидове Megeje до истоимене трагедије Велимира Лукића.

Кључне речи: антика, трагедија, Еурипид, Велимир Лукић, трансформација, Медеја.

Једна је само истина о нама:

Све што знамо гнусна је тама.

Једна је само истина о мени:

Ноћ, пакао и понор црвени.

Једна је само реч у устима мојим:

Добра нема, а зла се не бојим.

(Велимир Лукић, Ойало лишће)

Мит ћемо посматрати као причу, што је у кореспонденцији са Аристотеловим становиштем, причу која је најважнији сегмент трагичке радње и основа сваке трагедије. Аристотел под причом подразумева „састав догађаја” (Аристотел 1966: 16), што значи след радњи које формирају структуру трагедије. Ерих Фром (2003: 159) такође дефинише мит као причу која се одвија у одређеном времену и простору и преноси „кроз језик симбола религијске и филозофске идеје, као и искуства душе, у којима је стваран значај митова”. Мит захтева радњу да би структура била одржива. У трагедијама које 
су засноване на миту радња се сматра једним од основних конструктивних елемената. Трагичка радња мора бити јединствена, како је наведено у $O \bar{u} e-$ сничкој умейносиии:

„Прича не постаје јединствена, као што неки мисле, ако узима за предмет једно једино лице. Јер, као што се једноме лицу многе и неизбројне ствари дешавају, од којих неке не представљају никакво јединство, тако и међу радњама једнога лица има много таквих које се никако не могу повезати у једну јединствену радњу" (Аристотел 1966: 20).

Мит може бити перципиран на више начина; први је својствен интерпретаторима који не схватају суштину мита и виде га као „наивну слику света и историје”, док са друге стране постоји веровање да митови преносе истиниту и веродостојну слику света и догађаја (Фром 2003: 159). Свакако да мит није само „производ маште 'примитивних' народа”, већ представља „сећање на прошлост” (Исто). Алексеј Лосев (2000: 27) о миту закључује да „Мит није научна нит, посебно, примитивно-научна конструкција, него живо субјект-објектно узајамно општење које у себи садржи властиту, ваннаучну, чисто митску истинитост, веродостојност и принципијелну законитост и структуру”. У античким трагедијама мит се доживљава као историја једног народа и једног времена, кроз њега се преносе велике истине људског постојања у које се није ни сумњало. Као такав, мит је погодан за интерпретацију и реинтерпретацију, што постаје манир у књижевности. Модерна књижевност је истицала потребу за повратком у сферу деловања мита, његовог преиспитивања и даље ремитологизације, при чему на темељима већ написаног настаје нови дискурс. У раду ћемо настојати истаћи поменуте идеје и путање развоја митова и њихове трансформације од антике до модерног доба, тј. од античке Megeje до модерне Megeje.

\section{СТРУКТУРАЛНЕ РАЗЛИКЕ ПРИЧЕ}

Структурално посматрано, постоје значајне разлике између Еурипидове и Лукићеве Megeje, као што су очигледне и сличности. Када се говори о Еурипидовој Megeju, са освртом на чињеницу да је то античка трагедија, она представља изразиту структуралну иновативност, али је традиционална у смислу каузалности радње и композиције (увод, заплет и расплет) (в. Тодоровић 2017: 234-235). Еурипид је успео, упркос традиционалним нормама, да готово потпуно ослободи свој драмски дискурс дидаскалија, које је свео на минимум, да нижим друштвеним слојевима додели значајне реплике и да их одузме одређеним лицима као што су дечаци. У својој Меgеји успева да изгради комплексну структуру односа лица, која се касније у Лукићевој трагедији додатно усложњава. Компаративно посматрано, Лукићева Megeja 
прати структуру коју је успоставио антички трагичар допуњујући је модерним формама.

Дидаскалије су оскудне у обема трагедијама, готово да их и нема, а ненавођење опсежних дидаскалија је специфичан драмски поступак којим се користе и Еурипид и Лукић у сврху истицања тока приче и карактера лица. У обема Megejaмa неће бити од пресудног значаја положај лица или место дешавања јер је исходиште догађаја Медеја сама, о чему сведочи и чињеница да сва лица долазе Медеји, а она не прилази никоме. Док Еурипид у трагедију уводи кроз ниже друштвене слојеве (дадиљу и учитеља), који изражавају страх од Медејиних поступака, код Лукића Медеја прва проговара у дијалогу са дадиљом представљајући се као преварена и осрамоћена жена. Еурипид се служи оваквим приступом у трагедији јер жели да истакне утисак о Медеји, коме се и она сама подређује, што је очигледно у честим исказима који се односе на потенцијални смех њених непријатеља. Лукић инсистира на Медеји као лику који дела, осветници и победници, што истиче чињеницом да она уводи у трагедију, чиме бива јасно да ће и водити читаву радњу. У обема трагедијама Медеја је средиште радње, она је централни лик, што кореспондира захтевима античке трагедије, ништа се не догађа без њеног присуства или утицаја.

За разлику од свеприсутне Медеје у Еурипидовој и Лукићевој обради мита постоје лица чије су судбине унапред одређене, што исходи из одлука главног лица. Објективизација поменутих лица иде до крајњих граница, па није неопходно ни њихово присуство на сцени, већ је довољно да Медеја изрекне свој суд о њима. Елементи декора су у обема трагедијама исти ликови, са напоменом да у Еурипидовој трагедији дечаци проговарају, мада остају елемент декора јер њихов исказ не може променити њихову судбину (Тодоровић 2017: 241). У Лукићевој Меgеји дечаци не проговарају и не налазе се на сцени, о њиховим удесима чак неће бити ни детаљног извештаја. Глаука ${ }^{1}$ као елемент декора (Тодоровић 2017: 241) нема ни име у Еурипидовој Меgеји, док се у Лукићевој именује, али не проговара. Код Еурипида одређене реплике јасно упућују на присуство лица на сцени која не проговарају, такозване personae mutae (Маричић 2009: 26): „Пратња ће моја избацити те силом!” (Еурипид 2009: 26), док у Лукићевој Меgеји лица која не проговарају а налазе се на сцени нема. У Лукићевој трагедији постоје лица која припадају декору, али се она и не појављују на сцени, какви су Медејини и Јасонови синови и Глаука. Њихово непојављивање представља врхунац објективизације лица чија судбина зависи од Медеје, ради симболичког истицања осветнице као средишта и исходишта трагедије.

Троугао око кога се формира радња (Медеја-Јасон-вереница) је неизмењен, али је у Лукићевој Медеји очигледан и други троугао који фор-

${ }^{1}$ У Еурипидовој Megeju није ни именована, чиме трагичар жели да истакне заосталост и небитност њене личности у поређењу са Медејом (Ђурић 1962: 363). 
мирају Егеј, Медеја и Јасон. Пол Жинестје дефинише претходно поменуте ситуације у троуглу, при чему истиче да се најчешће среће сукоб две жене око једног мушкарца (Жинестје 1981: 131). Да би сукоб могао да се реализује једна страна троугла увек представља закониту везу, тј. брачну заједницу (Жинестје 1981: 131). Сходно наведеном, Еурипидов троугао је специфичан по супротстављању најављене законите везе (Јасона и Креонтове ћерке) и већ постојеће брачне заједнице (Медеје и Јасона), где нова нужно ништи прву. Разлог за Јасонову женидбу Медејом може бити дефинисан као прорачунати поступак, што сам брак одређује као опозит „стварној вези душе” (Дил 1991: 185). Тежња за настанком новог троугла изазива страх од Медејиних поступака, али и неспутану мржњу у њој као угроженој. Симболички значај чедоморства се може препознати у мотиву „детета - плода делатности (узвишене или изопачене)”, при чему је мајка убица „представница разорних сила подсвести" (Дил 1991: 189). Угроженост Медеје као супруге резултира идејом о чедоморству, које није само чин освете, већ и поступак аутодеструкције. Падуано (2011: 80) га назива апсурдним самоповређивањем. Дозвољавајући да улога супруге надвлада улогу мајке, Медеја се формира као страшна фигура преображаја материце која порађа у губицу која прождире, постајући симболом „смртоносне посуде” (Брил 1993: 58). Јасон је лице које формира два троугла односа, али је и Медеја теме које конструише два троугла - једном већ припада и не може да га измени (Јасон, она и нова вереница), док други ствара сама уводећи Егеја. Нови троугао који формира Медеја има основе у миту по ком чаробница са Егејем напушта град и у Атини му роди сина. Увођењем лика Егеја, и у Еурипидовој и у Лукићевој трагедији, Медејино касније чедоморство не бива схваћено само као реакција очајне преварене жене, већ свестан акт освете (Снел 1999: 151). Првенствено, помен Егеја је у сагласју са митским предлошком, а Медеја је увођењем Егеја обезбедила последњи сегмент освете, уточиште. У Еурипидовој трагедији епизода са Егејем се окончава његовим обећањем да ће Медеја добити уточиште ако га сама потражи у Атини: „Кад дођеш, учинићу све, како је право, да будем ти штит. Нешто ти, ипак, жено, унапред рећи морам: из Коринта ја те одвести нећу! Сама ако у дом стигнеш ми, безбедна бићеш и ником те не дам!” (Еурипид 2009: 40). По миту, након убиства Јасона и деце, Медеја се удаје за Егеја и заједно добијају сина Меда, а Медеја бива прогнана из Атине тек кад њена превара око непрепознавања Тезеја и Егеја бива разоткривена. Еурипид занемарује Медејину удају за Егеја пренаглашавајући Егејеву жељу за потомством ${ }^{2}$, а Лукић трансформише део у коме Медеја покушава да сакрије идентитет оца и сина у пролазност телесне љубави. Плотска љубав између

${ }^{2}$ Егеј као лице превазилази улогу спасиоца и пружаоца уточишта чињеницом да је онај који жуди за Медејом (доживљавајући је као средство којим ће добити потомство). Као такав, он постаје „ситуациона фигура желиоца” (Грандић 2009: 94). 
мушкарца и жене преноси емоцију психолошке драме са лица, тј. са сцене, на публику, тј. читаоце (Грандић 2009: 96), чиме се постиже свеобухватност. У Лукићевој Megeји разлог за прогон Медеје из Атине није епизода са Тезејем, већ Егејева минула занесеност и импресионираност Медејиним телом, што се сматра значајним одступањем од мита.

\section{ЕТИЧНОСТ - КОНСТИТУЕНТ ТРАГЕДИЈЕ}

Читава Еурипидова трагедија Megeja је одраз песниковог песимизма, његова представа људске природе, света и друштва (Кохан 1971: 231). Лексеме које песник користи у оквиру своје драме и изговара их кроз своје ликове показује да основа трагедије није изванредни и непоновљиви догађај, већ свакидашња појава, одраз обичног живота (Исто 1971: 231). Тај свет је свет сурових жена које могу убити своју децу зарад освете или из срдње што не могу убити правог кривца, мушкарци могу напустити породицу и узети другу жену зарад моћи и власти, свет убистава и освете, а да нема ни чуђења. Слика света у Лукићевој Megeји није драстично измењена, поједини поступци главне јунакиње су одмеренији и смисленији јер је она као лице комплекснија, што не утиче на промену средине или социјума. Кроз реплике својих лица Еурипид ће проговорити о темама које га интригирају, међу којима је и положај жене у друштву, што ће представити кроз Медејин исказ:

„Од бића свих, срце и ум штоно их красе, ми, жене најнесрећнији смо сој. Прво, за дебело благо мужа мораш да купиш, и он господар тела је твог. Рђавог ако ли узмеш, тада још веће је зло. Ризик је грдан: да л' биће муж добар ил' лош? Развод на зао износи те глас, а просца одбити не смеш. Нове кад обичаје и законе сретнеш - јер такве код куће немаш - пророчки дух треба да имаш у свему да угодиш мужу. [...] Укућани кад додијају мушкарцу, он оде од куће да одмори душу. Ми гледати смемо једино њега! Кажу да наш безбрижан је живот, у кући смо само, док они војују копљем. Немају појма! Радије трипут у бој бих пошла, него једно родила дете!” (Еурипид 2009: 23-24)

Проговарање о карактеру жена и истицање стања њихове душе доводи до промишљања о „социјалној запостављености жена”, са напоменом да Еурипид заузима критички став и апелује да се стање измени у корист жена (Црепајац 1974: 19). Поред критике положаја жене која је јасна и објективна, мада је често његов однос према женским ликовима изразито негативан, очигледна је Еурипидова наклоност према варварима. Често се истиче отуђеност, неразумевање које је у спрези са удесом варваризма: „Ја сам сама, домаје немам, гази ме човек из варварске што ме оте земље. Мајке немам, ни брата, рођака, места немам од несреће да склоним се!" (Еурипид 2009: 24). На тај начин се жена доводи на сцену као „психолошки проблем” (Црепајац 
1974: 19). Како Кохан (1974: 235) наводи, „епоха егоизма и помамне конкуренције" начинила је јединствен тип жене, јер је жена сходно свом положају у друштву могла да дела само у оквиру породице. Када јој је једини аспект живота на ком она има слободу егзистенције угрожен (Јасон напушта породицу и жели да се обавеже другој жени и оснује другу породицу), она се не осећа само пониженом већ отуђеном и дезинтегрисаном, што изазива потребу за осветом и потпуним уништењем изазиваоца несреће. До специфичног конфликта долази у Медеји самој због обичаја које је рођењем у варварској средини усвојила да би касније удајом морала да их прилагоди. Она није у потпуности прихватила нови поредак - да јесте никада не би дошло до њеног супротстављања - што упућује на чињеницу да постоје тачке подударања али и потпуног разилажења општеприхваћених моралних начела и Медејиних личних ставова.

У европској традицији, митови о Медеји и Јасону и њихове варијанте оформљени су искључиво по моделу Еурипидове трагедије (Слапшак 2006: 299). Модерна европска књижевност је, чини се, склона посебном истицању мотива брачних проблема (Исто), при чему су важне политичке или филозофске идеје скрајнуте, али је тема неверства и браколомства увек актуелна. У Лукићевој Megeju значајно се мање говори о положају жена него код Еурипида, али се више пажње посвећује Медејином варваризму и варваризму уопште. Мноштво информација о животу варвара износи сама Медеја:

„Богињо, да л” видиш ово? Да ли постојиш

Уопште, уображена богињо што чуваш брак?

$[\ldots]$

Док живех у својој земљи

Међу варварима, за тебе богињо,

Нисам знала, али знадох бракове вечне и божанске.” (Лукић 2009: 101)

„Али ми варвари, у једној љубави васпитавани

И само за једну љубав учени, не можемо

Заблуде хеленске примати, зато што је гесло то.

$[\ldots]$

Земљом се гордим својом, тужне певајући песме варварске.” (Лукић 2009: 101)

У ставовима и исказима дадиље у Лукићевој Меgеји видан је негативно конотиран однос према варварима и наклоност Хеленима, чак је често и наклоњена Јасону као представнику Хелена (што се сматра значајним одсту- 
пањем од Еурипидовог модела $\left.{ }^{3}\right)$. Како је у трагедији наведено: „Не слушај је племенити Јасоне [...]” (Лукић 2009: 114), „Како си речит, мужевни Јасоне” (Исто: 116), „Збогом, Госпо, не могу да слушам лажи из уста / Варварских о херојима нашим" (Исто: 117). Ово се сматра значајним одступањем у односу на еурипидовску традицију, јер су у његовој Меgеји сви подређени Медејином лику, нижи друштвени слојеви су јој наклоњени и чак пренаглашавају страх од деловања њеног беса (Тодоровић Васић 2019: 15). Јасно је да код Лукића не опстаје Еурипидова наклоност варварима, већ бивају и строго критиковани, он дозвољава да и нижи друштвени слојеви (дадиља) проговоре о варварском животу.

\section{МЕДЕЈИНО ТРАГИЧНО НАЛИЧЈЕ}

Медеја је као митска личност прецизно одређена, у смислу да је унука бога Сунца и Хекатина ћерка (Речник ірчке и римске мийолоїије 1987: 249), заљубила се у Јасона одлуком богова, па је због те љубави напустила домовину и начинила низ моралних погрешака. Божанско порекло је унапред одреЂује као сујетну, срдиту и осветољубиву ${ }^{4}$, док је чињеница да је многа недела учинила због Јасона, који је напушта, дефинише као незаустављиву деструктивну силу. Пошавши од мита, Еурипид своју трагичку јунакињу гради на бесу и срџби преварене и остављене жене, па бива очигледно да је основни конституент њеног трагичког карактера однос са Јасоном. Лукићева Медеја је комплекснија, у смислу да је одмеренија и промишљенија, не дозвољава да је воде искључиво страсти и бес. Специфичан је сукоб два принципа унутар ње, апсолутно-вечно и променљиво (Маричић, Шаховић Мишић 2009: 9), са тим њена покретачка сила није произашла само и искључиво из Јасонове преваре, већ и из личне потребе за славом. У тој потреби за славом бива слична античким херојима, са којима је повезује и непреиспитивање сопствених поступака и одсуство кајања због њих. Она једноставно дела зарад славе и страха који ће изазивати помен њених поступака. Еурипидова Медеја не испољава сличне тежње, она страхује да ће јој се непријатељи смејати, али не чини чедоморство нити спроводи освету како би је се плашили. Античка Медеја и пре своје појаве на сцени изазива стрепњу и страх код осталих лица трагедије, страх који је изазван самим сећањем на недела која је починила зарад другог (Јасона) и стрепњу на шта је спремна зарад себе.

Медеји је, још од почетног мита, супротстављен Јасон у смислу да он представља персону жеље, а Медеја је персона која планира, дела и испуња-

${ }^{3}$ У Еурипидовој трагедији дадиља изражава жељу да помогне Медеји, да је утеши и смири, чак је не назива варварком већ „избеглицом” и „својом госпом” (Еурипид 2009: 18).

${ }^{4}$ У вези са Медејиним пореклом је и навод: „Исконске мајке ретко су кад искључиво добре, те Велике Богиње најчеће представљају убилачки вид” (Брил 1993: 63). 
ва Јасонове намере. Читаво друштво је Јасону приписало заслуге, а Медеју одредило чарањем и неделима, при чему је ипак неоспорна чињеница да јунака Јасона не би било да није било Медеје као такве. Требало је да Јасон буде херој који је савладао „искушења изопачене владавине и разврата” и онај који ће владати очевим престолом освојивши „снагу духа и чистоту душе" (Дил 1991: 178), али он одабира да искористи Медејину моћ која симболише „дрскост према духу”, што је опозит херојском чину (Исто: 186). Упркос начину на који постиже жељено, он се формира као херој, освајач златног руна, али остаје каузално повезан са својом супругом. Одвајањем Јасона од Меде је, његовим ништењем брачне заједнице, од мушкарца хероја, онога који је успео да освоји златно руно, остаје само име (Црепајац 1974: 19), што је карактеристично за Еурипидово стваралаштво - он једноставно инсистира на свакидашњости и обичности, чак и херојску судбину оставља у прошлости. Милош Ђурић (1962: 365) Јасона назива „бедним плашљивцем и себичним циником", истичући да он чак живи у убеђењу да је сваки његов поступак мудар и одобрен, што га додатно чини трагичним. Лукићев Јасон је свестан карактера са којим се сукобљава, он је тај који и упозорава Креонта на шта је Медеја све спремна, али је на самом крају трагедије онај који нема мисао, нема емоције, а нема ни снаге да се покрене. Како је у трагедији наведено: „Стани, стани! И без мржње хоћу да те убијем, без икаквог порива, тек да бих нешто учинио. Али свеједно, свеједно да ли си мртва, не постојиш, јер иста си као и ја постала" (Лукић 2009: 140). Од митског прорачунатог хероја који је уживао наклоност богиња остала је љуштура без сврхе, кажњена сопственом егзистенцијом.

За Медејино чедоморство везано је више верзија мита (в. Речник ірике и римске мийолойије 1987: 250; Лески 1995: 189), при чему је јасно да интерпретатор или реинтерпретатор одабира верзију која је најпогоднија или чак комбинује све доступне варијанте стварајући посебну творевину. Свакако да се сам чин симболички везује за Кроноса (в. Керењи 1994: 65), али и Ламију, која је по миту отимала и прождирала украдену децу (в. Брил 1993: 103). Сматра се да је Еурипид одабрао верзију у којој је Медеја представљена као чедоморка, за шта се наводе многобројни разлози, од личних до тврдње да једноставно није желео да се стравични чин чедоморства заборави (Керењи 1994: 54). Еурипидовску традицију интерпретације мита о чедоморству Лукић ће само наставити. Треба истаћи да однос према чедоморству у античком свету Еурипидове трагедије и у Лукићевој обради није исти. Превасходно, српска књижевност, али шире посматрано и европска књижевност, одређене су „сакрализацијом мајчинске љубави”, а чин чедоморства се сматра неприхватљивим, због чега Еурипидова обрада мита представља проблемску ситуацију са којом је немогуће суочити се (Слапшак 2006: 299). Античко позориште се склања од стравичних сцена убистава и страдања тако што их не изводи на сцени, већ даје извештавања или сведочења да су се збили. 
Највише што обичаји антике могу допустити јесте одјек посмртних крикова дечака које прати хор, као у Еурипидовој Меgеји (Тодоровић Васић 2019: 16). У Лукићевој Megeju је овај сегмент митске радње неизречен, што подразумева да нема описа чедоморства, постоје само наговештаји да је до њега дошло: „Причекај Егеју! Да синове своје спречим да Хелени постану [...] Али Медеја зададе Медеји реч, да све хеленско око себе и у себи уништи. Затвори очи Медејо, нека ти проста рођена крв" (Лукић 2009: 119-120), као и реплика у којој Егеј потврђује да Медејину освету најбоље памте Јасонови синови, у којој бива јасно да их је мајка убила ради освете. Наведеним се изнова потврђује да је поступак чедоморства ситуација коју је немогуће посматрати, зато и остаје у форми непосредног извештаја.

Велимир Лукић се пишући своју Меgеју користи истом верзијом као и Еурипид, занемарујући остале, што нас доводи до претпоставке да као извор и користи Еурипидову трагедију. Прекори чедоморки постоје и у Лукићевој и у Еурипидовој трагедији, а последњи прекор изриче супруг. Код Еурипида Јасон, који је и отац, а код Лукића Егеј, који нема деце (Кохан 1971: 230). Медејино чедоморство назива истребљењем Јасоновог рода (што и Лукићев Егеј напомиње називајући дечаке „Јасоновим синовима”). Медеја, мајка, децу посматра као туђу, Јасонову, синове издајника, убија их да би се осветила мужу ког не може да убије (Кот 1974: 247), што је супротно традиционалном партријархалном начелу да жена треба мајчинством да учврсти брак, при чему је више носилац него стваралац живота (Тодоровић 2018: 12). Основна функција продужења мужевљевог рода рађањем потомства (Исто: 18) у Медејином примеру изазива потребу за деструкцијом, што је наговештава као представницу матријархата. Медеја и у Еурипидовој и у Лукићевој трагедији тешко и споро доноси одлуку о чедоморству, мада је мучно премишљање посебно наглашено у античкој трагедији. Специфично је да нема развоја плана за убиство деце, постоји мисао о чину, поверавање хору и сам чин, што нас изнова враћа на мисао да Медеја убиством деце убија своју везу са Јасоном и њега самог.

Медеја у Еурипидовој трагедији показује да је исходиште свега у човеку самом. Значајно је напоменути да је Медеја чаробница, унука бога Сунца, што нужно захтева успостављање поретка ствари према њој (Тодоровић Васић 2019: 14). Одређење чаробнице трагичку јунакињу смешта у сферу „симбола просте изопачености” (Дил 1991: 189), а Лукићева Медеја не одступа од наведеног, још је наглашенија њена самосталност и одлучност, којом поставља себе у средиште из кога све исходи. Наведена поставка је видна у односу других лица и Медеје, јер сви долазе пред њу, она не прилази никоме, при чему се истиче њихов страх, али и зависност од Медеје (Тодоровић Васић 2019: 14). У Еурипидовој Медеји трагички сукоб је вишеструк и формиран је око Меде је као централног лица и Креонта, Јасона, хора, мада је специфичан и интрасубјекатски сукоб (Исто). Лукићева Медеја не испољава интра- 
субјекатски агон, она је сигурна у своју одлуку и не премишља се превише. Она ипак ступа у сукобе са Креонтом, Јасоном и Егејем и из свих иступа као победник. У Лукићевој драми Медеја је хероина, не карактеришу је као код Еурипида поједине лексеме, бес, срџба, већ помен онога што жели да постигне својим подухватима. Она жели славу и изазивање страха при помисли на њена дела, у томе је слична Ахилеју који бира кратак, али славан живот. Митски карактер чедоморке Медеје се трансформише у Лукићевој драми у односу на Еурипидову. Лукићева Медеја је усредсређена искључиво на себе, у њој је јако изражен ерос, али и потреба за славом, док Еурипидова Медеја више страхује да ће јој се непријатељи смејати него што жели да буде славна.

Медеја као херојска фигура мора своје намере да сакрије од осталих лица у драми (Нокс 1999: 103). У Еурипидовој Меgеји трагичка јунакиња своје намере открива само хору Коринћанки, који је подржава и свим намерама осим у чедоморству (Тодоровић Васић 2019: 19). Хор у Еурипидовој трагедији саосећа са Медејом, што је последица чињенице да га чине жене: „Несрећна жено, вај! Кукавна ти си са својих јада! Куда да кренеш? У којој земљи гостопримној, у дому ком спас ћеш од невоља наћи?” (Еурипид 2009: 27). Хоровођа који најчешће проговара као појединац, али изричући став колектива супротставља се Јасону речима: „Лепо си, Јасоне, накитио говор. Ал' мени се, макар противречила теби, чини да то што жену остављаш нимало правично није” (Еурипид 2009: 34). Цинично и подругљиво обраћање Јасону је како очигледна подршка Медеји тако и општи став о браку и породици као темељу свих друштвених конструкција, чијим рушењем се деградира целокупан систем. Отворена и директна подршка Медеји јењава при помену чедоморства: „Зар дрзнућеш се, жено, пород свој да побијеш?” (Еурипид 2009: 43), што прераста у вапај и очајање због коначне одлуке о убиству деце.

У Лукићевој Megeји наведена су два хора, хор коринтских девојака и хор атинских грађана и, мада постоје два хора као одраз два различита принципа, њихове реплике су значајно мање у односу на Еурипидову трагедију. Поред смањених реплика, ови хорови у одређеним сегментима трагичке радње само подржавају лице чији су представници, не одричу њихове поступке или намере. Овиме бива јасно да хорови немају за сврху истицање моралних начела, већ једноставно имају функцију пратње главне радње. Хор коринтских девојака не одступа значајније од Еурипидовог хора Коринћанки, што је очигледно у репликама утехе: „Тужна Медејо, како да те исцелимо?” (Лукић 2009: 104). Мада, у дијалогу са Јасоном не постоји улога хора, већ је ту улогу преузела дадиља, а од пресудне важности је њена наклоност Јасону (за разлику од Еурипидове трагедије у којој у истом сегменту дискурса хор деградира Јасона). Улога Лукићевог хора у спречавању чедоморства је потпуно занемарена, нема изражене критике Медејине намере ни покушаја утицања на њу. Лукићева Медеја своје намере не разоткрива никоме у драми, постоје само наговештаји, али све чини сама без помоћи или подршке било 
ког другог лица, па је у том смислу самосталнија и страшнија од Еурипидове варварке. Хор атинских грађана се појављује у дијалогу са Егејем и истиче: „Медеју варварку не треба жалити. Месецима смо трпели њену охолост” (Лукић 2009: 123). Овај хор подржава, чак и бодри и правда Егејеву одлуку да отера Медеју. Поред чињенице да је хор атинских грађана заступник мушког, владарског принципа, представља значајну измену у односу на Еурипидову трагедију, са напоменом да у њој и није могао да се појави, јер је део мита о Медејиној удаји за Егеја Еурипид у потпуности занемарио.

\section{ЗАКЉУЧАК}

Мит је у форми дискурса погодан за интерпретацију и трансформацију, а због своје природе и структуре је увек актуелан. Посебно су погодни митови који се тичу свакодневних проблема и породичног живота, јер су као такви свевремени. Прича је одређена кључним догађајима који чине њену стабилност и за њих можемо рећи да су непроменљиви, њихово место је одређено каузалношћу тока времена и одређености простора. Развој поменутих догађаја и њихово повезивање у целину, као и одабир сегмента целокупног мита којим ће се новонастали текст бавити, посебно је умеће и поступак, што и сачињава кључну разлику у обрадама митова.

Од Еурипидове верзије трагедије о чаробници Медеји до Лукићеве обраде одређени елементи су трансформисани, али су многи и остали исти или веома мало кориговани, што говори превасходно о природи теме. Можемо слободно тврдити да у обема трагедијама нема драстичних одступања од примарног мита, свакако постоји одабир једне од верзија мита, што не утиче на перцепцију трагичке радње, јер и Еурипид и Лукић користе исту верзију. Еурипидова трагедија се не бави другим љубавним троуглом, ЈасонМедеја-Егеј, чак га потпуно занемарује споредним сусретом Егеја и Медеје који се завршава јасним наводом да до брака неће доћи. Поменути елемент представља значајну трансформацију у односу на примарни мит, што Лукић неће користити у својој драми. Лик Медеје је у Лукићевој драми у односу на Еурипидову зрелији и усмерен искључиво ка себи, не формира се око интрасубјекатског сукоба. Лукићева Медеја није нагла при првом сусрету са Јасоном и није јој неопходна подршка, она је сама себи покретачка сила. Иако су поједине разлике очигледне, Еурипидова и Лукићева Медеја су херојске фигуре, обе се на самом крају уздижу као победоносци без кајања. 


\section{ИЗВОРИ}

Еурипид (2009): Еурипид, Медеја, у: Три Меgеје, Београд: Паидеа.

Лукић (2009): Велимир Лукић, Медеја, у: Три Megeje, Београд: Паидеа.

\section{ЛИТЕРАТУРА}

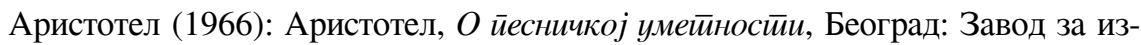
давање уџбеника Социјалистичке Републике Србије.

Брил (1993): Жак Брил, Лилий или мрачна мајка, Нови Сад, Сремски Карловци: Издавачка књижарница Зорана Стојановића.

Грандић (2009): Александар Грандић, Једна заборављена јужносрбијанска драма: српски национални покрет у драми Зайочници Анђелка М. Крстића, у: Узgaница, бр. 1 (2009), 91-102.

Дил (1991): Пол Дил, Симболика у ірчкој мийолойији, Нови Сад, Сремски Карловци: Издавачка књижарница Зорана Стојановића, Добра вест.

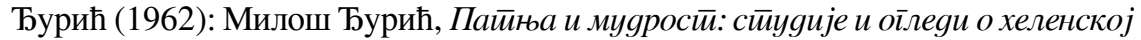
йрайеguји, Титоград: Графички завод.

Жинестје (1981): Пол Жинестје, Драмска геометрија, у: Моgерна йеорија gраме, приредила Мирјана Миочиновић, Београд: Нолит.

Керењи (1994): Карољ Карењи, Кћери суниа, Чачак: Дом културе.

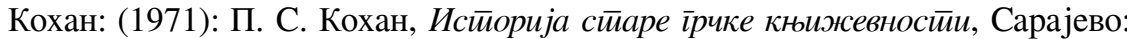
Издавачко предузеће „Веселин Маслеша”.

Кот (1974): Јан Кот, Јеgене бойова, Београд: Нолит.

Лески (1995): Албин Лески, Грика итрайеgија, Нови Сад: Светови.

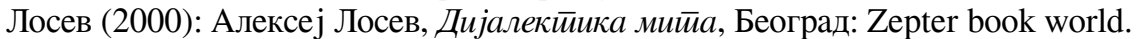

Маричић, Шаховић Мишић (2009): Горан Маричић, Србислава Шаховић Мишић, Три митске самотнице и три наше савременице, у: Три Megeje, Београд: Паидеа.

Нокс (1999): Бернард Нокс, Еурипидова Меgеја, у: Ойшйа књижевносй: изабрана йумачења, приредио Зоран Милутиновић, Београд: Филолошки факултет; Крагујевац: Нова светлост.

Падуано (2011): Гвидо Падуано, Анйичко йозоришӣe, Београд: Clio.

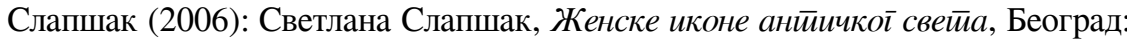
Библиотека XX век.

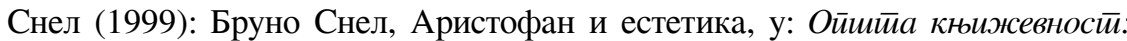
изабрана йумачењ $а$, приредио Зоран Милутиновић, Београд: Филолошки факултет; Крагујевац: Нова светлост.

Срејовић, Цермановић Кузмановић (1987): Драгослав Срејовић, Александрина Цермановић Кузмановић, Речник трике и римске мийолоіије, Београд: Српска књижевна задруга.

Тодоровић (2017): Јелена Тодоровић, Структуралне вредности Еурипидове Megeje, у: Лийар бр. 64, Крагујевац: Универзитет у Крагујевцу.

Тодоровић Васић (2019): Јелена Тодоровић Васић, Лик Медеје у Еурипидовој трагедији, у: Зборник раgова са Х скуйа млаgих фбилолоїа Србије, Крагујевац: Филолошко-уметнички факултет. 
Тодоровић (2018): Јелена Тодоровић, Конфигурација женских ликова у Роману о Александру Великом, у: Узgаница ор. 1(2018), 7-20.

Фром (2003): Ерих Фром, Заборављени језик: увоg у разумевање снова, бајки и митиова, Београд: Завод за уџбенике и наставна средства.

Црепајац (1974): Љубомир Црепајац, Предговор, у: Траїеgије, превео Милош Н. Ђурић, Београд: Просвета.

\section{Jelena M. Todorović Vasić}

University of Kragujevac

Faculty of Philology and Arts

Department for Serbian Literature

\section{REMYTHOLOGIZATION OF EURIPIDES' MYTHICAL FORM IN VELIMIR LUKIĆ'S MEDEA}

Summary: The paper deals with a comparative analysis of Velimir Lukić's and Euripides' tragedies, with particular reference to the transformed elements in the both tragedies in comparison with the original Greek myth of Medea. Similarities and differences between the two tragedies are comparatively analysed. The myth is of a ritual character, which implies the reinterpretation of certain archetypical, mythical stories and personalities. Some transformations can be explained by the influence of the spirit of the epoch in which the play was written or the personality of the author himself. Compared with other Greek tragedians, Euripides was considered an innovator in ancient times, which made him an inspiration for centuries. The segments of the original myth of Medea that have been altered or adapted in both Lukić's and Euripides' tragedies were compared and analysed. The aim of the paper is to highlight these segments and their path of transformation from antiquity to modern times.

Keywords: antique, tragedy, Euripides, Velimir Lukić, transformation, Medea. 